UNIO - EU Law Journal. Vol. 4, No. 1, January 2018, pp 102-116.

(2018 Centre of Studies in European Union Law

School of Law - University of Minho

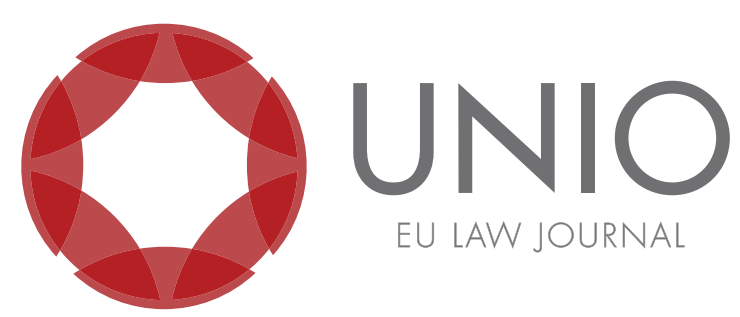

\title{
The new market abuse directive in the Portuguese legal order
}

\author{
Joana Whyte*
}

ABSTRACT: This paper offers an analysis of the Portuguese Legal Order regarding Market Abuse and Insider Dealing and also of the existing legal instruments for these matters - the Portuguese Securities Code. Essentially, it expresses how, over the past few decades, the Portuguese legislator has been tackling these issues, bearing in mind that Portugal started legislating on these issues even before the first Communitary Directive, implemented in 1989. Considering that, in April 2014, the European Union adopted a new Market Abuse Directive (MAD) imposing a duty on Member States to settle criminal sanctions, the main issue we addressed is how this new legal instrument affected the Portuguese legal order.

KEYWORDS: market criminality - market protection - information - Portuguese Securities Code - Market Abuse Directive.

\footnotetext{
* Associate Lawyer at SRS - Sociedade Rebelo de Sousa \& Advogados Associados, R.L., in the Competition and EU Law Department. Collaborating member of the Centre of Studies in EU Law (CEDU) of the University of Minho. Master's Degree in European Union Law by University of Minho. Law Degree by University of Coimbra.
} 


\section{Introduction}

The international financial crises had a tremendous impact within Europe but particularly on the southern European countries. Portugal itself was severely affected. With the financial crises came the bankruptcy of private Banks and companies, and, of course, with bankruptcy, many cases of insider dealing, market abuse and overall corruption were made public. This situation reignited the debate on the need for more severe legislation and penalties.

Due to the Framework Decisions and Directives adopted (both before and after the entry into force of the Treaty of Lisbon in 2009) we have witnessed an "europeization" of criminal law, beyond the initial need to protect Europe's financial interests and aimed more towards the development of a solid, cohesive European criminal law.

The ongoing historical context shows the need to consolidate the illegal nature of insider dealing - as well as other phenomena connected with economic activities. This particular context also shows that market globalization justifies the need for the harmonization of legal instruments. The reason for the criminalization of situations characterized as market abuse, includes the need to ensure the integrity of financial markets and to promote investors' confidence in it, forbidding practices which cast doubt on integrity, resulting in an increase in investment, and the consequent improvement of the European economy. The necessity of criminalizing insider dealing arises from the need to prevent opportunistic behaviour based on the dissemination of asymmetric information.

The conditions for the smooth functioning of the securities markets should be preserved for several reasons: because they are channelled to market the savings of investors, both for a relationship between the visibility of the issuer and for the interest generated by the trading of assets in the market; because the negotiation, in itself, generates information for investors in terms of quantities, prices and market trends; and also because the prices that are generated in a regulated market are public price references used in numerous public and private decisions. If negotiations take place for the free balancing of supply and demand, the market trends which they form are real. Otherwise they may be artificial and misleading for the various economic actors and public authorities.

\section{Approximation of substantive Criminal Law}

To a certain extent, the European Union's founding fathers overlooked the importance of the enforcement of Community law. This led to the enforcement of several policies in favour of the autonomy and discretion of Member States - namely regarding the agricultural and fisheries policy, Community customs code, European financial services regulations, EU subsidy fraud rules, European environmental policy and European rules on corporate law.

The European Commission soon became aware of the enforcement gap in the Treaties, and accordingly, in 1976, the Commission made an attempt to complement the Treaties with protocols concerning fraud and corruption by Community officials. Despite these efforts, neither protocol gained the political approval of the Council. With the support of the European Parliament, the Commission was already then of the opinion that there was a considerable enforcement deficit on the part of Member States when it came to compliance with European policies. Therefore, the Commission submitted several concrete legislative proposals to the Council aiming 
at obliging Member States to use both punitive administrative law and criminal law in the enforcement of Community law. Many of these proposals were approved by the Council, obliging Member States to impose punitive administrative sanctions, especially in the area of common agricultural policy.

This emerging influence of EU law on the law of punitive sanctions was not applauded by all Member States. In 1990, Germany brought an action for annulment of Regulation (EEC) n'. 3007/84, from 26 October 1984, ${ }^{1}$ and Regulation (ECC) $n^{\circ}$, 1260/90, from 11 May $1990,{ }^{2}$ both concerning agricultural policy, before the Court of Justice. The Regulations not only prescribed restitution (with a surcharge) of subsidies that had been unjustifiably obtained, but also punitive exclusion from subsidy schemes. Germany was of the opinion that the European Community did not have the power to prescribe punitive sanctions. In 1992, in a landmark decision, the Court of Justice ruled that the European Community was competent to adopt the measures, including the punitive sanctions. ${ }^{3}$

Work on approximating substantive criminal law began within the European Union under the third pillar of the Treaty of Maastricht. Examples of this are the 1995 Convention on the protection of the European Community's financial interests, ${ }^{4}$ the 1997 Convention on the fight against corruption, ${ }^{5}$ or the different joint actions adopted at the time in the field of participation in a criminal organization, ${ }^{6}$ trafficking in human beings ${ }^{7}$ and other subjects.

Work was also pursued under the Treaties of Amsterdam and Nice. Within this framework, and mainly on the basis of article 31 (e) of the Treaty on the European Union ("TEU"), a substantial number of initiatives in the field of approximation of substantive criminal law were put forward. Framework decisions were adopted in the fields of terrorism, ${ }^{8}$ trafficking in human beings, ${ }^{9}$ sexual exploitation of children and child pornography, ${ }^{10}$ smuggling of human beings, ${ }^{11}$ counterfeiting of euros, ${ }^{12}$ fraud

\footnotetext{
${ }^{1}$ OJ, L, no. 283, p. 28; EE 03 F32 p. 161.

${ }^{2}$ OJ, L, no. 124 , p. 15.

${ }^{3}$ Case 240/90, from 27 October 1992, Germany v. Council and Commission, ECR, p. I-5383.

${ }^{4}$ Convention of 26 July 1995 on the protection of the EC's Financial Interests (OJ, no. C 316, 27 November 1995, p. 49 f).

${ }^{5}$ Convention of 26 May 1997 on the fight against corruption involving officials of the EC or officials of Member States of the EU (OJ, nº. C 195, 25 June 1997, p. 2).

${ }^{6}$ Joint Action of 21 December 1998 on making it a criminal offence to participate in a criminal organization in the Member States of the EU (OJ, nº. L 351, 29 December 1998, p. 1 f).

${ }^{7}$ Joint Action of 24 February 1997 concerning action to combat trafficking in human beings and sexual exploitation of children (OJ, nº. L 63, 4 March 1997, p. 2 f).

${ }^{8}$ Framework Decision 2002/475/JHA of 13 June 2002 on combating terrorism (OJ n ${ }^{\circ}$. L 164, 22 June 2002, p. 2 f) and Framework Decision 2008/919/JHA of 28 November 2008 amending Framework Decision 2002/475/JHA (OJ, n. L 330, 9 December 2008, p. 2 f).

${ }^{9}$ Framework Decision 2002/629/JHA of 19 July 2002 on combating trafficking in human beings (OJ, no. L 203, 1 August 2002, p. 1 f).

${ }^{10}$ Framework Decision 2004/68/JHA of 22 December 2003 on combating sexual exploitation of children and child pornography (OJ, nº. L 13, 20 January 2004, p. 44 f).

${ }^{11}$ Framework Directive of 28 November 2002 on the strengthening of the penal framework to prevent the facilitation of unauthorised entry, transit and residence (OJ, no. L 328, 5 December 2002, p. 1 f).

${ }^{12}$ Framework Decision 2000/383/JHA of 29 May 2000 on increasing protection by criminal penalties and other sanctions against counterfeiting in connection with the introduction of the euro (OJ, $\mathrm{n}^{\circ} . \mathrm{L}$ 149, 14 June 2000; Framework Decision 2001/888/JHA of 6 December 2001 amending Framework Decision 2000/383/JHA (OJ, nº. L 329, 14 December 2001).
} 
and counterfeiting of non-cash payments, ${ }^{13}$ corruption, ${ }^{14}$ drug trafficking, ${ }^{15}$ racism and xenophobia ${ }^{16}$ cybercrime, ${ }^{17}$ among others. Some of these acts were second generation instruments which simply replaced previous joint actions.

The Treaty of Lisbon provides for a new legal framework for criminal legislation and for the punishing of crimes committed within the area of freedom, security and justice. This Treaty changed the substance of criminal law harmonisation, the applicable rules and the objective of harmonisation. ${ }^{18}$

The first reference to approximation is made in article 67 (3) of the Treaty on the Functioning of the European Union ("TFEU"). ${ }^{19}$ In this article, approximation is referred to as one of the measures that can be used to ensure a high level of security. However, approximation appears in this article after coordination and cooperation measures and after mutual recognition. To finish, the European legislator states that the use of approximation should only occur "if necessary", which reflects the delicacy of this topic.

Article 67 (3) of the TFEU consecrates not only the principle of mutual recognition of judicial and extrajudicial decisions and the right of access to justice which are essential elements for the functioning of the internal market as well as European citizenship in the dimension of freedom of movement.

We must also note that article 67 (1) of the TFEU, binds the development of the area of freedom, security and justice to the "respect for fundamental rights and the different legal systems and traditions of the Member States".

The approximation of substantive criminal legislation is of paramount importance, as it aims at enhancing the fight against criminality and preventing criminals from benefiting from the existing disparities between Member States' criminal laws. On the other hand, it also ensures the development and exercise of free movement of persons within the EU, it reinforces the notion of European citizenship and provides citizens with a common sense of justice throughout the Union which creates a feeling of belonging to a common area.

The adoption of the Treaty of Lisbon established a new legal basis for the adoption of legal instruments for criminal procedural law - article 82 of the TFEU and for substantive criminal law - article 83 of the TFEU. Prevention and punishment of criminality in the European Union has become an objective related not only to the

\footnotetext{
${ }^{13}$ Framework Decision 2001/413/JHA of 29 May 2001 combating fraud and counterfeiting of noncash means of payment (OJ, nº. L 149, 2 June 2001).

${ }^{14}$ Framework Decision 2003/568/JHA of 22 July 2003 on combating corruption in the private sector (OJ, nº. L 192, 31 July 2003).

${ }^{15}$ Framework Decision 2004/757/JHA of 25 October 2004 laying down minimum provisions on the constituent elements of criminal acts and penalties in the field of illicit drug trafficking (OJ, $\mathrm{n}^{\circ}$. L 335, 11 November 2004).

${ }^{16}$ Framework Decision 2008/913/JHA on combating certain forms and expression of racism and xenophobia by means of criminal law (OJ, nº. 328, 6 December 2008).

${ }^{17}$ Framework Decision 2005/222/JHA of 24 February 2005 on attacks against information systems (OJ, n. L 69, 16 March 2005).

${ }^{18}$ Article 3 of the Treaty of the European Union states that "The Union shall offer its citizens an area of freedom, security and justice without internal frontiers, in which the free movement of persons is ensured in conjunction with appropriate measures with respect to external border controls, asylum, immigration and the prevention and combating crime".

${ }^{19}$ About the interpretation of article 67 read António Vitorino, "Artigo 67", Tratado de Lisboa Anotado e Comentado, ed. Manuel Lopes Porto and Gonçalo Anastácio (Coimbra: Almedina Editora, 2012) $371-373$.
} 
free movement of persons, but also to citizens' rights and duties.

According to the wording of article 82 of the TFEU, harmonisation of procedural and substantive criminal law is a necessary tool for strengthening judicial cooperation in criminal matters based on mutual recognition and mutual trust. Considering the scope of this study, we will focus only on the provisions of article 83.

Under article 83 (1) of the TFEU, ${ }^{20}$ the European Parliament and the Council are competent to adopt directives in the areas of particularly serious crimes with crossborder dimensions resulting from the nature or impact of such offences or from a special need to combat them on a common basis. Article 83 (1) of the TFEU allows for the development of approximation independently of any other ongoing EU work. This article establishes a list of ten serious areas of criminal activity with cross-border dimensions for which the EU holds a legislative competence, the so-called "eurocrimes". ${ }^{21}$

Article 83 (2) of the TFEU provides for the so-called "annex-competence". ${ }^{22} \mathrm{In}$ this article, the EU's competence is enlarged if the approximation of criminal laws and regulations of the Member States proves essential for ensuring the effective implementation of a Union Policy in an area which has been subject to harmonisation measures guaranteeing their "effet utile". This provision allows for the extension or diversification of the areas in which approximation is carried out and most likely opens the door to a very broad criminal law competence. ${ }^{23}$

Article 83 (3) of the TFEU provides a so-called “emergency break". When a Member State considers that a draft directive would affect fundamental aspects of its criminal justice system, the ordinary legislative procedure is suspended and the proposal is referred to the European Council. If, within four months, unanimity is reached, the draft is referred back to the Council and the suspension is lifted. If an agreement is not reached in the European Council, a group of at least nine Member States can establish enhanced cooperation.

The legal basis for the adoption of the MAD is article 83 (2) of the TFEU - this was in fact the first Directive adopted under said article. This Directive is part of a legislative double text package, which also includes a Regulation on insider dealing and market manipulation (Regulation (EU) n. 596/2014 of the European Parliament and the Council, from 16 April 2014). The prevention and effective punishment of market abuse can only be achieved through the integration of EU and national criminal policies. ${ }^{24}$

\footnotetext{
${ }^{20}$ About the interpretation of article 83 see Anabela Miranda Rodrigues, "Artigo 83", Tratado de Lisboa Anotado e Comentado, ed. Manuel Lopes Porto and Gonçalo Anastácio (Coimbra: Almedina Editora, 2012) 434-438.

${ }^{21}$ Terrorism, trafficking in human beings, sexual exploitation of women and children, illicit drug trafficking, illicit arms trafficking, money laundering, corruption, counterfeiting of means of payment, computer crime and organised crime.

${ }^{22}$ Anne Weyembergh (in collaboration with Serge de Biolley), "Approximation of substantive criminal law: The new institutional and decision-making framework and new types of interaction between EU actors", Approximation of substantive criminal law in the EU: The way forward, ed. Francesca Galli and Anne Weyembergh (Brussels: IEE, 2013), 16.

${ }^{23}$ Anne Weyembergh (in collaboration with Serge de Biolley), "Approximation of substantive criminal law...", 17.

${ }^{24}$ John A. E. Varvaele, "Harmonised Union policies and the harmonisation of substantive criminal law", in Approximation of substantive criminal law in the EU: The way forward, ed. Francesca Galli and Anne Weyembergh (Brussels: IEE, 2013), 69.
} 


\section{The Portuguese legal order}

European Directive 89/592/EEC, of 13 November 1989, ${ }^{25}$ coordinating regulations on insider dealing, imposed the approximation of Member States' legislations on the subject. This Directive identified insider dealing as a factor capable of jeopardizing the markets' functioning. This Directive underlined the fundamental role of the "secondary market in transferable securities in the financing of economic agents" and highlighted the close connections between the markets' proper functioning and investor confidence. In order to preserve these assets - the proper functioning of the market and investor confidence - the Directive imposed the prohibition on certain behaviours, but article 13 allowed Member States to decide on the penalties to be applied for infringement of the measures taken pursuant to it. This Directive was transposed into the Portuguese Legal order, however, the illegal nature of insider dealing and a concept of market manipulation had already been established in the Code of Commercial Companies (Código das Sociedades Comerciais) which had entered into force in 1986, ${ }^{27}$ even before the adoption of Directive 89/592/EC.

The Code of Commercial Companies established the illegal nature of insider dealing and contemplated non-penal sanctions - the obligation to compensate the injured, judicial dismissal of the responsible agents and judicial investigation (articles 449 and 450 of the Code of Commercial Companies).

Later on, in 1987, the Code was amended ${ }^{28}$ and a title on penal and administrative offences was introduced, including the crimes of insider dealing in article 524, and fraudulent manipulation of the market in article 525. The explanation for this event is laid down in the preamble to the Decree-Law which approved this amendment stating that "we attempted to preserve within these offenses, without direct correspondence in the Penal Code, in addition to the essential language of precision, a global connection to the structure of the classic offenses, so that the work of jurisprudence still finds plenty of guidance and support in the system of concepts and principles of criminal law. It must be noted that these provisions, as with other similar rebound in corporate life, start from a pedagogical intent: they aim to contribute to the consolidation of economic rules and correct habits and business' ethics". ${ }^{29}$ After unveiling the focus on company ethics, it is not surprising that the crime of insider dealing, in the Portuguese legal order, begins by being established in the Code of Commercial Companies and by targeting firstly the members of the administration and the auditory bodies of limited liability companies (sociedades anónimas), or those who illegally reveal information obtained through the service provided to the company to a third party (information which had not been disclosed before).

The reorganization of the Portuguese securities market which was undertaken in 1991 was organized from a long list of administrative offences and only three crimes were included: market manipulation, insider dealing and disobedience, the first two revoked the equivalent crimes of the former Code of Commercial Companies from $1987 .{ }^{30}$ This modification to the legal framework is very important because it

\footnotetext{
${ }^{25}$ Council Directive 89/592/EEC of 13 November 1989 coordinating regulations on insider dealing, OJ L 334, 18.11.1989, 30-32.

${ }^{26}$ Recitals of the Council Directive 89/592/CEE, from 13 November 1989, coordinating regulations on insider dealing.

${ }^{27}$ Decreto-Lei n. $^{\circ}$ 262/86, de 02/09, available at www.pgdl.pt.

${ }^{28}$ Decreto-lei 262/86, de 2 de Setembro, available at www.pgdl.pt.

${ }^{29}$ Decreto-lei 262/86, de 2 de Setembro, available at www.pgdl.pt.

${ }^{30}$ Comissão de Mercado de Valores Mobiliários, Contra-Ordenações e Crimes no Mercado de Valores
} 
demonstrates the connection between insider dealing and the securities market. ${ }^{31}$ The model adopted in 1991 remains effective until today.

This dualistic legal structure - establishing administrative sanctions and crimes - allowed a clear separation between contraventions of duties whose compliance is revealed necessary to ensure the fair and proper functioning of the market, and facts with the more severe and inexcusable capacity of injuring, which causes damage to the legal interests essential to the organization, structure and functioning of this sector of the financial system, and which deserve criminal protection afforded by being considered as crimes against the market. ${ }^{32}$

Generally, the administrative offences against the market correspond to illegalities of a professional character or dangerous, dysfunctional or harmful market activities. These illegalities may constitute a violation of the Portuguese Code of Securities, as well as other national or European specific legislation.

Different sanctions correspond to this dichotomy of infractions, which are applied by different authorities - the administrative sanctions are applied by CMVM (Comissão de Mercado de Valores Mobiliários, the Portuguese Securities Market Commission); for crimes against the market, the Portuguese judicial authorities have exclusive competence (however, CMVM is competent to carry out preliminary inquiries which may turn out to be the grounds for a reasoned criminal investigation).

The administrative offenses are unlawful acts resulting in financial penalties (fines) and sanctions (e.g. temporary prohibition of a certain activity), and also the added specific legal consequences such as loss of economic benefits obtained from the illegal behaviour. On the other hand, criminal acts are punishable with penalties including imprisonment and fines, accompanied by accessory penalties provided for in the Portuguese Securities Code (temporary professional ban and publication of the judgment) and loss of economic benefits obtained from the crime committed as a legal consequence thereof.

The administrative penalties established in the Portuguese Securities Code $(\mathrm{CdVM})^{33}$ impose responsibilities on the agents if their conduct was intentional or negligent, but, crimes against the market are only considered as such if they were intentional.

With the adoption of this model, the legislator was able to effectively articulate three different levels of supervision: a permanent administrative action monitoring the activity of agents and operations in the market; an immediate punitive punishment, which was to act as a deterrent and extended to all market segments of activity (through administrative offenses); and an ultima ratio option, limited to the most serious cases representing the functional denial of the market.

Nowadays, within the Portuguese Legal Order, the crimes of insider dealing and

Mobiliários, July 2009, available at http://www.cmvm.pt/pt/EstatisticasEstudosEPublicacoes/ Estudos/EmArquivo/Documents/ContraOrdenacoeseCrimes199120091.pdf.

${ }^{31}$ José de Faria Costa, O Crime de Abuso de Informação Privilegiada (insider trading) a informação enquanto problema jurídico-penal, (Coimbra: Coimbra Editora, 2006) 28.

${ }^{32}$ Comissão de Mercado de Valores Mobiliários, Contra-Ordenações e Crimes no Mercado de Valores Mobiliários, July 2009, available at http://www.cmvm.pt/pt/EstatisticasEstudosEPublicacoes/ Estudos/EmArquivo/Documents/ContraOrdenacoeseCrimes199120091.pdf.

${ }^{33}$ Código dos Valores Mobiliários - Decreto Lei n. ${ }^{\circ}$ 486/99 de 13 de Novembro, available at http:// www.pgdlisboa.pt/leis/lei_mostra_articulado.php?nid=450\&tabela=leis\&so_miolo=\& $\quad$ (access: October $\left.1^{\text {st }} 2017\right)$. 
market manipulation are established in the Securities Code. ${ }^{34}$ The Portuguese Securities Code was published in 1999, it grouped the crimes of insider dealing and market manipulation in a section dedicated to "crimes against the market". Furthermore, in 2005, a law which authorizes the Government to legislate on crimes of insider dealing and market manipulation was published, establishing the conditions for the transposition of Directive 2003/6/CE of the European Parliament and the Council, of 28 January 2003, on insider dealing and market manipulation (market abuse). ${ }^{35}$ The Directive from 2003 established a general "framework of principles" 36 on tackling the crimes of insider dealing and market manipulation. ${ }^{37}$

The Portuguese Securities Code currently in force considers insider dealing and market manipulation as crimes against the market. Therefore, in order to protect the market, we must protect information.

Portuguese legislation was adopted in order to transpose, into national law, the Directive under scrutiny - it was dealt with under national Law n ${ }^{\circ} .28 / 2017$, of 30 of May. However, main changes concern making the national legislation's adaptation to Regulation 596/2014 clear and not, in a specific and biding way, transposing Directive 2014/57/UE.

\section{The previous regime}

\section{a) Insider Dealing}

Securities markets rely on information that is essential for decisions by investors, companies and regulators. The origin, nature and function of some of this information is at times reserved to a limited circle of people, becoming accessible to the general public at a later stage. The time of disclosure and quality of information to be disclosed, among other things, affect and influence the agents' decisions in the market and have a significant impact on the formation of prices.

Portuguese law prohibits the transmission and improper use of such information if it has not been made public. Before that, its use is restricted or even prohibited. Furthermore, we must ensure access to information by the majority of investors in conditions of equality, using the time the information was made public as a reference. The transmission or improper use of inside information before it has been made public may jeopardize the proper functioning of the market, it may frustrate ongoing operations and generate illegitimate advantages for some investors at the expense of others. So the law considers that such facts constitute a crime when committed intentionally by individuals.

By banning these acts, criminal law aims to strengthen investor confidence in the functioning of the securities markets, regulating the conditions of the relevant information and the possibility of negotiating its use. The definition of insider dealing was laid down in article 378 (3) of the CdVM (Portuguese Securities Code) as: "information which has not been made public, being precise and relating directly or indirectly to any issuer or any securities or other financial instruments would be likely if it were made public, to have a

\footnotetext{
${ }^{34}$ Idem.

${ }^{35}$ Guido A. Ferrarini, "The European Market Abuse Directive”, Common Market Law Review 41 (2004): 711-741.

${ }^{36}$ José de Brito Nunes, "Notas pessoais sobre o processo Lamfalussy", Cadernos do Mercado de Valores Mobiliários 18 (2004): 48.

${ }^{37}$ Helena Bolina, "A manipulação de mercado e o abuso de informação privilegiada na nova Directiva sobre abuso de mercado (2003/6/ CE)”, Cadernos do Mercado de Valores Mobiliários 18 (2004): 62.
} 


\section{significant effect on the markeet'.}

For the adoption of the concept of inside information in Portuguese law it was also relevant to analyse article 248 (2) of the CdVM, which explained the scope of some elements of the concept in more detail: "inside information includes the facts that occurred, existing or are reasonably foreseeable, regardless of their degree of formalization, which, because they are likely to influence the pricing of the securities or financial instruments, any reasonable investor would normally use if had known them in order to base all or part of their investment decisions".

The legal concept (article 378 (4) of the CdVM) required that, for the relevant information to be considered privileged, it must contain four characteristics: information which is (1) non-public, (2) specific, (3) accurate (precise) and (4) likely to have a significant price effect if it were made public. These four aspects of inside information have been detailed by doctrine, case law, but also by regulators of the various countries and international bodies, such as the Committee of European Securities Regulators (CESR). ${ }^{38}$ The information is not public when it has not been made accessible to most investors, and it is specific when it comes, directly or indirectly, to any issuer or the securities or financial instruments.

The other two requirements of this legal concept - its precise nature and price sensitive information - were achieved in article 248 (2) of the CdVM which was expanded upon in the second round of CESR's advice on this matter. ${ }^{39}$ Hereunder, some aspects relevant to the assessment of these essential conditions for qualification as privileged information are set out.

The information must be of a precise nature. The determination that we are facing a fact which has already occurred, is existing or which is reasonably foreseeable to occur characterizes the precise nature of the information, thus distinguishing it from mere rumour or speculation.

For the information to be accurate, there is no need for it to be complete or permanent, if the information relates to a process which takes place over several stages (as is the case in the preparation of a public offer of acquisition - OPA), not only the entire process taken as a whole, but also each separate phase can be considered accurate information. The fact that the process will not be completed does not exclude the information on the occurrence of a stage of the process from being considered accurate.

This guidance from CESR corresponds to the understanding that has been followed by the Portuguese courts (Criminal Courts and Courts of Appeal) ${ }^{40}$ in applying the concept of inside information in phased business processes (such as the preparation of a friendly takeover bid), assigning independent status to each step of the decision making process, contact and negotiations between the parties (considering each set of facts in itself as inside information), and not limited to the end result of it or the pricing to offer. Knowing these facts in any stage prior to the final outcome of the business gives the insider an advantage before other investors, an advantage which the insider cannot legitimately use. The information is accurate when it has a degree of

\footnotetext{
38 Luigi Foffani, "Nuevas Tendencias Y Perspectivas del Derecho Penal Economico Europeo", Revista Portuguesa de Ciência Criminal 24/ 2 (2014): 225-234; Comissão de Mercado de Valores Mobiliários, Contra-Ordenações e Crimes no Mercado de Valores Mobiliários, July 2009, available at http://www.cmvm.pt/pt/EstatisticasEstudosEPublicacoes/Estudos/EmArquivo/Documents/ ContraOrdenacoeseCrimes199120091.pdf.

${ }^{39}$ Report of the Committee of European Securities Regulators CESR/06-562 b, July 2007, available at https://www.esma.europa.eu/system/files/06_562b.pdf.

${ }^{40}$ Porto Court of Appeal, Judgment from 31/05/2012, available at www.dgsi.pt.
} 
significance which allows it to be used.

In the formulation of the law, this happens when the information allows us to draw a conclusion about its possible impact on prices, consequently allowing us to make an investment decision involving a very low financial risk.

The information has yet to be suitable to significantly change the price (price sensitive information). The susceptibility of the information to influence the price should be assessed ex ante, which means it must take into account the degree to which it would be expected that this information had, or would have had, an effect on market prices, if it had been disclosed at the time the fact occurred or before the information was made public. The suitability of the information is evaluated through a hypothetical reasoning: if the fact was known by the market at that time, would this have produced a significant change on asset prices?

The criterion for determining this susceptibility in done to the standard of a reasonable investor: in relation to price sensitive information, the information which any reasonable investor might normally use, if he had had access to it, on which to base all or part of his investment decisions.

To be able to characterize this susceptibility of influencing prices, we must, in particular, take into account the following factors: the predicted magnitude of the act in question in the context of the business; the relevance of the information to the main determinants of the price of the financial instrument; the credibility of the source; and the market variables that influence the price of the financial instrument. ${ }^{41}$

There are several examples of indicators that the information is likely to have an impact on the financial instrument's price: the type of information concerned is the same information that in the past, had an impact on prices; the type of information in question is normally taken into account as a factor for investment recommendations to take into consideration (e.g. to determine the price target); the information was expressly kept secret; and the issuer treated similar events in the past as inside information.

In addition to the general prohibition on the misuse of inside information set out in article 248 (4) of the CdVM, the incriminating types of insider dealing set out in article 378 describe a set of criminally prohibited behaviours. Therefore, the person who is in possession of inside information may not: transmit such information outside the normal scope of their duties; nor may they use this information, which means they cannot negotiate, advise someone to negotiate, sort, for themselves or others, directly or indirectly, the subscription, purchase, sale or exchange of securities.

The crime of insider dealing is imputable only to individuals and only if the behaviour was intentional. When, legal persons or individuals acting merely negligently are involved, they may be faced with the prescribed administrative offense provided in article 248 (4) of the CdVM, for the misuse of inside information. Legal persons may also be sued in criminal proceedings as civil parties for the purposes of article 378 (7) of the CdVM.

\section{b) Market Manipulation}

The reason for criminalizing conduct characterized as market manipulation was set out in the recitals of Directive 2003/6/EC of the European Parliament and the Council from 28 January 2003, as the need "to ensure the integrity of Community financial

\footnotetext{
${ }^{41}$ Comissão de Mercado de Valores Mobiliários, Contra-Ordenações e Crimes no Mercado de Valores Mobiliários, July 2009, available at http://www.cmvm.pt/pt/EstatisticasEstudosEPublicacoes/ Estudos/EmArquivo/Documents/ContraOrdenacoeseCrimes199120091.pdf.
} 
markets and to increase investor's confidence in those markets. It is therefore advisable to adopt combined rules to combat both insider dealing and market manipulation to ensure the integrity of Community financial markets and to enhance investor confidence in those markets. It is therefore advisable to adopt combined rules to combat both insider dealing and market manipulation". ${ }^{42}$

The Portuguese legal order had already established the crime of fraudulent manipulation of the market in the Code of Commercial Companies of 1987 in article 525, even before the adoption of Directive 89/592/EC. ${ }^{43}$ Currently, Portuguese law prohibits dealing or informative behaviours that, by their nature or consequences, might be able to create delicate situations over a security or an issuer. More precisely, article 379 (1) of the CdVM criminally prohibits the dissemination of false, incomplete, exaggerated or biased information and the act of carrying out fictitious transactions and performing other fraudulent practices. Behaviours which could artificially alter the normal functioning of the securities markets or other financial instruments.

In addition to these forms of manipulation, Portuguese law, from 1999, has provided for a specific crime that can occur within a financial intermediary: this crime can be committed by the members of the board of directors and those responsible for the management or supervision of areas of activity of a financial intermediary who, having knowledge of facts which constitute manipulation and which are performed by individuals directly subject to their supervision and in the exercise of their duties, do not put an immediate end to such behaviour (article 379 (3) of the CdVM).

The described facts can be committed if the act is officially committed and also in the form of a co-partnership as established in the Portuguese Criminal Code (Articles 26 and 27). The attempt is not punished.

Certain acts are excluded from the scope of prohibited behaviours, including: operations carried out by the European Central Bank, a State, its central bank or any other body designated by the State for reasons of monetary policy, exchange rate or public debt management (article 379 (6) of the CdVM); price stabilization operations, which are carried out under the legally permitted conditions (article 379 (6) of the CdVM); market-making operations under the law (Article 348 of the CdVM and Regulation 3/2007 CMVM); accepted market practices, whose identification, dissemination and communication is made pursuant to article 360 (1) (i) of the CdVM.

\section{c) Applicable Penalties and Sanctions}

Under Portuguese Law, insider dealing and market manipulation are punished with main and accessory penalties as well as with special juridical consequences, such as the loss of the economic advantage obtained from the crime. According to article 380 of the CdVM, accessory penalties are the temporary inhibition (no longer than five years) of the professional activity or an activity related to the crime and publication of the sentence in places in which the objectives of general prevention and market protection are achieved.

If the illicit act generates economic benefits for the defendant or a third person for whom the defendant negotiated including interest, profit or other economic benefit, those amounts will be apprehended or declared lost in the final decision.

\footnotetext{
${ }^{42}$ Recital 12 of the Directive 2003/6/EC of the European Parliament and the Council from 28 January 2003 on insider dealing and market manipulation (market abuse), OJ L 96, 12.4.2003, p. $16-25$.

${ }^{43}$ On the evolution of the criminalisation of market manipulation in Portugal see Claudia Verdial Pina, "Crime de manipulação do mercado: elementos típicos e recolha de prova", Revista Julgar 17 (2012): 37.
} 
If the insider dealing agent is an administrator of the company, or has access to the information due to their employment position, this is punishable with a maximum penalty of imprisonment for 5 years or with a fine; if the agent obtained the information through another means and negotiates or advises someone to negotiate in securities, the penalty is of 4 years of imprisonment or a fine until 240 days.

Under article 379 of the CdVM, the penalties for market manipulation are of a maximum imprisonment of 5 years or a fine. Members of the administrative body and the persons responsible for the general management or supervision of areas of activity of a financial intermediary who, being aware of the conduct, performed by individuals directly subject to their management or supervision and exercising their duties, do not put them to an immediate end may be punished with imprisonment up to 4 years or fine of up to 240 days if more serious penalty is applicable under another legal provision.

However, this regime is not applicable to transactions carried out by the European Central Bank, a State, its central bank or any other body designated by the State for reasons of monetary policy, exchange rate or public debt management or the operations of stabilization of prices, which are carried out under the legally permitted conditions.

The CMVM is the competent body for administrative offenses cases, with the authority to charge and decide. In these cases, preventive measures can be taken, such as the preventive suspension of particular activities or functions performed by the defendant, apprehension or freezing of values, or the imposition of an information duty. The administrative offenses can be very serious, serious our less serious. The fines applicable in each situation vary: for a very serious offense from $25000 €$ to 5.000.000€; for a serious offense from $12.500 €$ to 2.500.000€; for a less serious offense $2.500 €$ to $500.000 €$.

In addition to the application of a fine, under article 404 of the CdVM, additional sanctions can be cumulatively applicable, such as the apprehension and loss of the object of the infraction, including the benefit obtained from the illegal behaviour; temporary ban from the exercise of the profession or activity to which the offense relates; ban from the exercise of management functions, control or supervision of any financial intermediary within the market; withdrawal of the authorization or cancelation of the necessary registration for the exercise of market activities; and publication of the sentence in places in which the objectives of general prevention and market protection are achieved.

The determination of the applicable sanction - being a sanction or an accessory sanction - is regulated under article 405 of the CdVM, done depending on the material illegality of the act, the agent's negligence, the benefits obtained from the behaviour and prevention requirements, also taking into account the natural or legal nature of the agent.

The proceeds from pecuniary fines and seized benefits revert to the Investor Indemnity System (Sistema de Indemnização dos Investidores) and not the CMVM.

\section{d) Criminal Liability of Legal Persons}

Both individuals and legal persons can be held liable for administrative offences, together or separately, depending on their participation in the acts (article 401 of the CdVM).

For the crime of market manipulation and insider dealing, only individuals can be held liable and the agent must have acted with intent. For the crime of market abuse and insider dealing, if the agent who either practiced the crime or collaborated 
in it is a legal person, then, under Portuguese law, legal persons cannot be held liable in a criminal case. The responsibility of the legal person is excluded if the agent acted against their order. Therefore, in such cases a legal person can be held liable in criminal proceedings as a civil party under the terms and for the purposes of article 379 (5) of the CdVM, in an attempt to repair the damage or return the profit obtained from the crime. In the cases of administrative offenses there is no determination of civil responsibility. However, this does not mean that repairing damage is not important in an administrative offense case, the reparation of damages by the defendant is important to determine their responsibility.

\section{The transposition of the Directive - Law 28/2017}

The transposition of the Market Abuse Directive constitutes the thirtieth amendment of the Portuguese Securities Code. It entails the transposition of Directive 2013/50/EU of the European Parliament and Council of 22 October 2013 amending Directive 2004/109/EC of the European Parliament and of the Council on the harmonisation of transparency requirements in relation to information about issuers whose securities are admitted to trading on a regulated market, Directive 2003/71/EC of the European Parliament and of the Council on the prospectus to be published when securities are offered to the public or admitted to trading and Commission Directive 2007/14/EC laying down detailed rules for the implementation of certain provisions of Directive 2004/109/EC; Commission Implementing Directive (EU) 2015/2392, of 17 December 2015, on Regulation (EU) n'. 596/2014 of the European Parliament and of the Council as regards reporting to competent authorities of actual or potential infringements of that Regulation; and the adaptation of the Portuguese law to Regulation (EU) n ${ }^{\circ}$. 596/2014. As stated above, both the Market Abuse Directive and Regulation 596/2014 consist of a legislative double text package.

The new rules on market abuse update and strengthen the existing framework to ensure market integrity and investor protection. The Directive on Market Abuse complements the Market Abuse Regulation by requiring Member States to introduce criminal sanctions for the offences of insider dealing and market manipulation where these are committed with intent, and to impose maximum criminal penalties of not less than 4 and 2 years' imprisonment for the most serious market abuse offences.

The Market Abuse Regulation ensures regulation keeps abreast of market developments such as the growth of new trading platforms, over the counter (OTC) trading and new technology such as high frequency trading (HFT); strengthens the fight against market abuse across commodity and related derivative markets; explicitly bans the manipulation of benchmarks; reinforces the investigative and administrative sanctioning powers of regulators; and ensures a single rulebook while reducing, where possible, the administrative burdens on small and medium-sized enterprises issuers.

The main amendments to the Portuguese Securities Code were made in order to adapt Portuguese legislation to Regulation 596/2014. As far as the New Market Abuse Directive is concerned, no major amendments were made regarding the punishment of the concerned acts. In fact, the New Market Abuse Directive obliges Member States to implement criminal sanctions in their legal order whose maximum limit should not be less than four years for insider trading and manipulation market and two years for the crime of illegal transmission of privileged information, limits which our CdVM already provided for. We note that there are a few examples of omissions and incorrect transposition of the Directive. 


\section{a) Insider dealing}

Article 3 (3) (a) of the New Market Abuse Directive establishes that this article applies to any person who possesses inside information as a result of being a member of the administrative, management or supervisory bodies of the issuer or emission allowance market participant. We analysed the wording of the Portuguese, English, French, Spanish and Italian texts, and all of them chose the word "member" to identify the subject (in Portuguese "membro"). Nevertheless, the Portuguese legislator, in the transposition of this provision into article 378 (1) (a) chose the word "titular" instead of "membro". Article 378 (1) (a) reads as follows "due to his capacity as holder of an administrative, management or supervisory body of an issuer or of a shareholder in its capital". We understand that the wording chose by the Portuguese legislator for this article was unfortunate and may result in an incorrect interpretation and consequently application of this provision.

According to the previous regime, article 378 (2) already established the onward disclosure if inside information as follows: any person who, having knowledge of inside information, transmits the information to anotherperson or, on the basis of that information, negotiates or advises someone to trade in securities or other financial instruments or orders them to subscribe, sale, exchange, directly or indirectly, for themselves or another person, shall be punished with imprisonment up to 4 years or with a fine of up to 240 days. With the transposition of the New Market Abuse Directive, this article now includes the transmission of information to amend or cancel an order concerning a financial instrument therefore transposing the provision of article 3 (6) (b).

The concept of insider dealing contained in article 378 was expanded upon by the adoption of paragraph 5 of said article. So, according to article 378 (4) "insider information is all unpublished information which, being directly and indirectly accurate and related to any issuer or securities or other financial instruments, would be appropriate, if it were made public, to influence market in accordance with Regulation (EU) No 596/2014 of the European Parliament and of the Council of 16 April 2014 and its regulations and delegated acts"; paragraph 5 of said article adds to that concept the "information on outstanding orders on securities or other financial instruments transmitted by clients of financial intermediaries is also privileged, which is not public, is precise and directly or indirectly related to issuers or financial instruments, which, if it were made public, would be capable of appreciably influencing its price or the price of spot commodity contracts". The Portuguese legislator introduced article 378 A which provides a specific regime on insider dealing on emission allowances.

\section{b) Market Abuse}

Regarding Market Abuse, the Portuguese legislator introduced three new articles regarding market manipulation besides the existing article 379. These are: articles 379 A, B and C. Article 379 provides a general provision on market abuse. Articles A, B, C provide different specific regimes for emission allowances; spot commodities; and the manipulation of the calculation of a benchmark.

Article 379 (1), transposing article 5 (2) (a) (i), now expressly provides not only a prohibition on the dissemination of false, incomplete, exaggerated or biased information, but also misleading information. The penalty was not amended and therefore this crime is still punishable with a penalty of five years imprisonment or a fine. The amendment to article 379 went further. The legislator included, in paragraph 2 of the article, an independent criminalization of the artificial alteration of the regular functioning of the market punishable with a prison sentence of up to 8 years or a fine of up to 600 days. 


\section{c) Criminal Liability of Legal Persons}

Article 7 of the New Directive on Market Abuse imposes an obligation on Member States to take the necessary measures to ensure that legal persons can be held liable for insider dealing and market abuse. However, this is not news for the Portuguese legal order. Since the adoption of the Portuguese Penal Code of 1982, the criminal liability of legal persons, especially in economic law, has been accepted. Article 11 prescribed that "unless otherwise specified, only natural persons criminally liable". Article 401 of the CdVM already provided that both individuals and legal persons can be held liable for administrative offences, together or separately, depending on their participation in the facts.

\section{Concluding Remarks}

It is evident that the Directive itself did not entail a true reform of the Portuguese legal order. The main amendments to the CdVM were made not because of the Market Abuse Directive but because of Regulation (EU) n'. 596/2014. However, the relevance of this Directive must be analysed bearing in mind the importance of the approximation of national criminal policies within the EU regarding the prevention and effective punishment of market abuse and insider dealing. In fact, prevention and punishment of these crimes can only be achieved through the integration of EU and national criminal policies. As we have already stated above, the approximation of substantive criminal legislation is of paramount importance as it aims not only at enhancing the fight against criminality and preventing criminals from benefiting from the existing disparities between Member States' criminal laws; but it also ensures the development and exercise of free movement of persons within the EU and provides citizens with a common sense of justice throughout the Union, creating a feeling of belonging to a common area. 